\title{
CEsifo WORKING

\section{Water the Flowers You Want to Grow? Evidence on Private Recognition and Donor Loyalty}

Benjamin Bittschi, Nadja Dwenger, Johannes Rincke 


\section{Impressum:}

CESifo Working Papers

ISSN 2364-1428 (electronic version)

Publisher and distributor: Munich Society for the Promotion of Economic Research - CESifo

$\mathrm{GmbH}$

The international platform of Ludwigs-Maximilians University's Center for Economic Studies and the ifo Institute

Poschingerstr. 5, 81679 Munich, Germany

Telephone +49 (0)89 2180-2740, Telefax+49 (0)89 2180-17845, email office@cesifo.de

Editor: Clemens Fuest

https://www.cesifo.org/en/wp

An electronic version of the paper may be downloaded

- from the SSRN website: www.SSRN.com

- from the RePEc website: $\quad$ www.RePEc.org

- from the CESifo website: https://www.cesifo.org/en/wp 


\title{
Water the Flowers You Want to Grow? Evidence on Private Recognition and Donor Loyalty
}

\begin{abstract}
We study donor loyalty in the context of church membership in Germany. Church members have to make substantial payments to their church but can opt out at any time. In a large-scale field experiment, we examine how private recognition for past payments affects church members' loyalty. We find that recognizing past payments in a letter significantly reduces opt-outs. This effect is driven by members in the bottom quartile of baseline payments to the church. Consistent with optimization frictions prior to the experiment, we observe a spike in opt-outs immediately after treatment for particularly costly memberships.
\end{abstract}

JEL-Codes: D640, C930.

Keywords: private recognition, donor loyalty, charitable giving, field experiment, recurring donors.

Benjamin Bittschi

Institute for Advanced Studies

Vienna / Austria

bittschi@ihs.ac.at

\author{
Nadja Dwenger* \\ University of Hohenheim* \\ Stuttgart / Germany \\ nadja.dwenger@uni-hohenheim.de
}

*corresponding author

Johannes Rincke

University of Erlangen-Nuremberg / Germany

johannes.rincke@fau.de

June 19, 2020

We thank the Evangelical Lutheran Church in Bavaria and especially Johannes Bermpohl for partnership on this project. Nadja Dwenger thanks the German Research Foundation DFG (Information Provision and Tax Compliance of Firms and Individuals, DW75/1-1) and the German Academic Exchange Service for financial support. She conducted part of this research as a Visiting Researcher at Harvard University and at the University of California, Berkeley. The hospitality of the researchers at both institutions is gratefully acknowledged. We have benefited greatly from comments by Maja Adena, Mathias Ekström, Boris Hirsch, Daniel Kühnle, Marta Serra-Garcia, Mirjam Reutter, Nora Szech, Harald Tauchmann, and Lukas Treber. Philip Mielcarek and Daniele Pelosi provided excellent research assistance. 


\section{Introduction}

About half of worldwide donors are enrolled in a recurring giving program, defined as an open-ended schedule of recurring payments to a charity that the donor can terminate at any time. The average recurring donor will give 42 percent more in one year than those who give one-time gifts, and retaining recurring donors saves costs for charities compared to acquiring new donors (Nonprofit Tech for Good, 2019). As a consequence, the loyalty of recurring donors is of major importance for charitable organizations, such as religious and educational organizations, hospitals, and blood donor organizations (Notarantonio and Quigley, 2009; Bagot et al., 2016; Chuan et al., 2018; Council for Advancement and Support of Education, 2019).

Retaining the loyalty of recurring donors is an empirically important, but understudied objective of charitable organizations. Most existing papers (reviewed in Andreoni and Payne, 2013) focus on one-time donations. Such one-time donations are arguably very important to charities, and the literature has led to significant progress in understanding the optimal design of donation asks. However, it is unclear whether one-time donations and recurring donations respond similarly to charities' fundraising efforts (Sargeant, 2008), and studying one-time donations necessarily misses out many important aspects related to time (Chuan et al., 2018; Rooney et al., 2019). In particular, the literature on one-time donations cannot address the question of how to maintain donor loyalty.

This paper focuses on recurring donors. It provides the first field-experimental evidence on how private recognition increases the loyalty of recurring donors with a charity. ${ }^{1}$ Conceptually, private recognition can be understood as boosting the warm glow recurring donors experience when donating to the charity. The context of our study is charitable giving to religious organizations, which in the US and many other countries are the largest recipients of charitable donations (Andreoni and Payne, 2013). In this context, the warm glow experienced by recurring donors can take many forms, including the notion that one "is doing the right thing." Specifically, we study Protestant Church membership in Germany as a form of giving to a religious charity. Three

\footnotetext{
${ }^{1}$ In a study on new donors, Samek and Longfield (2019) find no effect of additional thank-you calls on the probability of recurring, possibly because of the co-existence of thank-you letters.
} 
key features of this context are relevant for our empirical analysis. First, church membership in Germany involves regular payments by the member to the church and is therefore akin to a recurring donor scheme. This is because church members pay an income-dependent contribution to the church, which is labelled 'church tax'. In 2018, the Protestant Church in Germany raised an average church tax of 270 euro per member (including non-tax paying members, Statistisches Bundesamt, 2019). Second, as in other recurring donor schemes, church members can terminate their involvement with the church at any time. After opting out, individuals no longer have to pay, but can still benefit from many church services (see Section 2 for details). Third, for decades church membership in Germany was very stable, with very low opt-out rates of members. In recent years, the annual rate of opt-outs from the Protestant Church (as from other churches) has steadily increased and reached one percent in 2018 (Statistisches Bundesamt, 2019). As church finances heavily rely on church tax revenues, the loss in tax-paying members poses a serious long-term threat to the church - as the loss of recurring donors would for many non-profit organizations.

To implement our randomized field experiment, we teamed up with the Protestant Church in the federal state of Bavaria. In collaboration with the church, we varied the recognition that church members experience for their payment by a letter treatment. In February 2015, roughly 200,000 church members were randomly assigned to a control group or a private recognition letter group. In the private recognition letter, the head of the church tax office thanked church members for their past payments and acknowledged these payments as "an important contribution to our community". Church members in the control group did not receive a letter. About two weeks after the mailing of treatment letters, the church contacted a subsample of 4,000 church members from both treatment and control groups with a postal survey. The survey questionnaire aimed at measuring how church members perceived the recognition of their payments by the church.

Our analysis of retention rates benefits from rich administrative data on Protestant church members. We combine individual data on church membership with church tax records. This allows us to link the church members' individual opt-out decisions to a number of individual characteristics, including past payments to the church. 
Our results are as follows. First, based on the survey data we demonstrate that the treatment letter successfully communicated church recognition of payments made. Treated survey respondents feel more recognized and hold more positive views on making payments to the church. Second, in the field experiment, we find that private recognition increases the retention rate among church members by as much as 10 percent for a period of up to ten months after treatment. The treatment effect tapers off over time, suggesting that renewed efforts are needed to maintain donor loyalty. Third, a heterogeneity analysis shows a monotonic relation between the cost of membership and the reduction in opt outs, with low-paying church members responding most strongly. Fourth, we document a sharp positive spike in opt-outs in the first month after treatment among church members whose individual cost of membership is in the top quartile. This spike is consistent with optimization frictions prior to the experiment, which delay opt-outs from high-cost memberships.

Our paper contributes to several important strands of the literature. It advances the established literature on charitable giving (reviewed in Andreoni and Payne, 2013). Recurring donors have not been in the focus of this literature, with few exceptions. Anik et al. (2014) explore the effectiveness of contingent matching incentives in turning one-time donors into recurring donors. Informing study participants on the impact of previous hypothetical donations was found to increase the willingness for subsequent hypothetical donations (Gilad and Levontin, 2017). Breman (2011) shows that charities can increase donations by allowing donors to commit to future donations. Our paper differs from the existing literature by focusing on existing recurring donors and ways to improve their loyalty.

By exploring the loyalty of donors, we add to the literature on the temporal nature of donation decisions. Several papers have focused on the sources of time inconsistencies in charitable giving (e.g., Rand et al., 2012, and Andreoni and SerraGarcia 2019,b), and on the impact of pledges on donations (with mixed evidence, see Lacetera et al., 2016 and Fosgaard and Soetevent, 2018). While future demands for payment were shown to decrease initial giving (Adena and Huck, 2019), previous donors are more likely to give (Levin et al., 2016), in particular if they were initially attracted by an economic mechanism (Landry et al., 2010). Also related is work on 
how fundraising activities shift donations over time (Scharf et al., 2017).

The paper also contributes to a broader literature on the effects of recognition. This literature has studied public recognition in the context of work (Kosfeld and Neckermann, 2011), tax compliance (Dwenger et al., 2016; Slemrod et al., forthcoming), political donations (Perez-Truglia and Cruces, 2017), and pro-social behavior (Ashraf et al., 2014; Chetty et al., 2014). In contrast, there is little causal evidence on private recognition. ${ }^{2}$ An exception is Samek and Longfield (2019), who find that thank-you calls do not affect the probability of new donors to make further donations to a charity. In contrast to Samek and Longfield (2019), we focus on long-term donors. Finally, our work also complements the literature on the underlying motives for charitable giving (List et al., 2019).

The remainder of our study proceeds as follows. The next section provides the institutional background. Section 3 describes our field experimental design and data. Section 4 summarizes our findings, and Section 5 concludes.

\section{Institutional Background}

Germany has a state church tax. ${ }^{3}$ Anyone who was ever baptized and has not opted out of her church membership is considered a church member. In Bavaria, all church members are liable to pay an additional 8 percent of their annual income tax to the church. The church collects the tax using income tax records provided by the state tax authorities. The tax is automatically deducted just like payroll taxes or social insurance. ${ }^{4}$ The church tax is the single main source of revenue for the churches in Germany. It raised 5.8 (6.6) billion euro for the Protestant (Catholic) church in 2018 (Statistisches Bundesamt, 2019).

Individuals can avoid paying the church tax by leaving the church: No further payments accrue when church members formally renounce their membership with an official declaration made in person at a district court. Non-members can still benefit

\footnotetext{
${ }^{2}$ Studies by psychologists suggest that private recognition reinforces benevolent behavior (McCullough et al., 2001) by making individuals feel socially valued (Grant and Gino, 2010).

${ }^{3}$ Similar taxes exist in Austria, Denmark, Finland, Iceland, and Sweden.

${ }^{4}$ In Bavaria, church members are also liable for a local tax which is much smaller in size, see Dwenger et al. (2016).
} 
from many church services: They can attend Sunday services, send their children to a church kindergarten or church school, and have family members taken care of in a church nursery home. ${ }^{5}$ In recent years, opting out of church membership has become much more common in Germany. In 2014, the year prior to our experiment, more than 270.000 (217.000) individuals opted out of the Protestant (Catholic) church. As a result, in the decade prior to our experiment, the population share of Protestant church members declined by about a quarter, from 34.6 percent in 1994 to 27.9 percent in 2014 (including children and other non-income tax paying individuals). The trend is even more pronounced among church tax payers, posing a serious long-term threat to church finances.

While the institutional setting of the Protestant Church in Germany allows us to run a large-scale field experiment on charity loyalty, a few features of church membership distinguish our setting from other recurring donor systems. First, the church offers a few private goods (church weddings, becoming godparents) that are only available for church members. This could raise loyalty with the church relative to other contexts and lead us to underestimate the effect of private recognition. However, it is not uncommon that charities offer private goods to recurring donors. For instance, in the United States, many parents are asked to regularly donate to their child's school, at the benefit of their child's education. Many non-profit organizations keep "circles of friends" to whom they offer special treatment such as participating in special events etc. Second, conditional on membership, payments to the church take the form of non-voluntary tax payments. While this feature and the labeling of the payments as a 'tax' may seem special, we would like to reiterate that church members can terminate their membership at any time, making the payments similar to pre-specified payment plans in a recurring donor scheme. In this sense, church membership works like a donation default, where excessive default amounts can lead to a negative extensive margin response (Altmann et al., 2019). Third, payments to the church are income dependent, leading to a rising individual cost of membership for members whose income increases over time. Again, similar features are not uncommon in other contexts in-

\footnotetext{
${ }^{5}$ Non-members can become witnesses of baptized children who are undistinguishable from godparents for observers. Bridal couples can get a church service if a least one partner is a member.
} 
volving recurring payments to charitable organizations. For instance, many non-profit organizations offer junior members a scheme with a step-wise increase in recurring payments over time, including scientific associations and universities' alumni associations.

\section{Experimental Design, Data and Postal Survey}

\subsection{Experimental Design}

In collaboration with the Protestant church in Bavaria, we designed a randomized field experiment to study how private recognition affects church members' loyalty with the church. In the experiment, we implemented a private recognition treatment. In a letter sent to a random subsample of church members, the head of the church tax office thanked the letter recipients for their church tax payments and acknowledged the payments as "an important contribution to our community" (see Figure A2 in the Online Appendix for a display of the treatment letter). Church members in the control group did not receive a letter.

According to surveys conducted by the Protestant church, the majority of people who terminated their church membership did so to avoid paying the church tax. Our experiment therefore focuses on church members at working age (aged 18-65), earning income liable to the church tax at baseline. Germany has a system with (optional) joint income tax filing of couples. ${ }^{6}$ Therefore, the unit of treatment in our experiment is the Protestant church tax unit, consisting of either a Protestant single filer, or a Protestant spouse in a jointly filing couple where the partner is not a member of the Protestant church, or a jointly filing couple where both spouses are members of the Protestant church. Couples where both spouses were Protestants received only one letter.

The sample for the field experiment consists of 198, 036 tax units with 239, 442

\footnotetext{
${ }^{6}$ For couples with two Protestant spouses, the Protestant church tax equals an additional 8 percent of the couple's personal income tax. In couples with one Protestant spouse only, the Protestant church tax corresponds to 8 percent of the couple's personal income tax times the Protestant's share of taxable household income.
} 
individual church members. ${ }^{7}$ Half of the tax units in the experiment were assigned to the treatment group $(N=119,613)$, and the remaining half to the control group $(N=$ 119,829). Treatment assignment was stratified, where the strata were defined by taxable income (below/above median), church members' age (below/above 35 years), and urbanization at place of living (rural, semi-urban, urban) ${ }^{8}$ The letters were sent out end of February $2015 .^{9}$

\subsection{Data}

We link data from two administrative data sources: records documenting all decisions by church members to opt out of their membership, and state income tax records. We consider opt-outs in the 12 months following the mailing of the treatment letters (March 2015 to February 2016) and link those records to the income tax records for the years 2013 and 2014.

After the mailing of the treatment letters, the church invited part of the individuals in the experiment to participate in a survey (see the following subsection for details). We exclude from the evaluation of the field experiment all church members who were invited to take part in the survey ( $N=3,965$ tax units with 4, 767 church members). We also exclude recipients who changed from joint to single filing (or vice versa) within 12 months after the mailing of the treatment letters $(N=1,025$ tax units with 1136 church members), as changes in the filing type are often associated with events like marriages, divorces or the death of a spouse that are known to trigger church opt-outs (or opt-ins). These exclusions leave us with 233, 539 sampled individuals.

The sampling for the field experiment was done shortly before the mailing of the letters. It was based on the church tax records for 2013. This is due to the fact that in

\footnotetext{
${ }^{7}$ The church asked us to exclude tax payers with taxable income above 250,000 euro from the experiment. The overall sample size of the field experiment was derived from power calculations with a minimum detectable effect of 10 percent, an opt-out rate of 1.5 percent (over a 12-month period) in the control group, a 5 percent level of statistical significance, and power of 80 percent.

${ }^{8}$ Based on the three stratification variables, we defined $2 \times 2 \times 3=12$ bins. All bins that featured annual opt-out rates of 1.3 or larger prior to the experiment were fully sampled; the sampling rate for the remaining bins was 56.2 percent.

${ }^{9}$ The trial covered in this paper was part of a bigger initiative by the Protestant church in Bavaria to improve the retention of tax-paying church members. As part of this initiative, the church also sent out a longer letter to inform individuals on how the church tax is spent. This letter was only sent to individuals who were not part of our experiment. A letter identical to our private recognition letter was sent out a year later (February 2016). This repeated recognition does not appear to shift behavior.
} 
Germany, personal income tax filing and assessment usually happens with a time lag of 15 to 24 months. As a result, at the time of sampling for the experiment, income records for 2014 were not yet available. This prevented us from conditioning the sampling on actual church tax payments in 2014. In the fall of 2016, we went back to the church tax records and added to our data base the tax data for 2014 that had become available in the meantime. Tax data for 2014 was available for a subset of 200, 784 church members only, for two reasons: falling below the tax exemption threshold, and not filing a tax return for 2014 until the fall of 2016. As many low- to moderate income earners (including most retired persons) do not have to file a tax return, we are more likely to obtain tax records for individuals with higher incomes. ${ }^{10}$ A possible concern could be that the sample of the experiment comprises some church members who were not liable for the church tax in the year before the experiment and, as a consequence, did not make any payment to the church. If assigned to the treatment group, those members may perceive the private recognition letter as inappropriate. Therefore, this paper focuses on the sample of 200, 784 individual church members for whom we observe taxable income and tax payments in 2013 and 2014. We refer to this sample as "estimation sample" and discuss the robustness of our findings regarding the sample definition in Section 4.

Online Appendix Table A1, Panel A presents evidence on sample characteristics and balance across treatment and control groups for the estimation sample. In our sample, the average annual taxable income in baseline year 2013 was about 48, 900 euro, resulting in an average annual payment for church membership of 478 euro. The average age of individuals in the experiment was 45 years. As noted above, the probability of tax information 2014 being available increases in income, leading to a larger share of individuals in the third and fourth quartile of the income distribution in our estimation sample. The table shows that the treatment and control groups are well balanced in observable characteristics.

\footnotetext{
${ }^{10}$ For church members in the bottom quartile of taxable income in 2013, we obtain tax records for 2014 in 81.8 percent of the cases. In the top quartile, this share is 89.4 percent.
} 


\subsection{Postal Survey}

About two weeks after the mailing of the treatment letters, the church contacted 3,965 randomly drawn church members (one half from the control group, and the remaining half from the treatment group) with a postal mailing containing a survey questionnaire. ${ }^{11}$ The mailing also included a return envelope that survey recipients could use to send back the questionnaire anonymously and free of postage. The questionnaire asked recipients to evaluate a number of statements on the church tax and on state taxes, using a 5-point Likert scale (from "fully agree" to "fully disagree"). A total of 1,022 church members (527 from the treatment group, and 495 from the control group) sent back the questionnaire (response rate: 25.8 percent). The survey questionnaires contained a pre-printed code that allowed us to recover from incoming questionnaires several key characteristics of the sender (the anonymity of survey respondents was retained).

Not surprisingly, survey response was selective with respect to respondents' observable characteristics. Panel B in Online Appendix Table A1 shows that relative to the overall sample of the experiment, survey respondents were more likely to belong to the top income quartile and were older. However, the survey respondents' observable characteristics were balanced across treatment and control groups. This allows for causal inference on how the private recognition treatment has affected perceptions of the church tax and of state taxes in the sample of survey respondents. ${ }^{12}$

\footnotetext{
${ }^{11}$ The sampling of the survey recipients followed the same stratification procedure as the treatment assignment. Couples with two Protestant spouses received only one questionnaire. The analysis is therefore done at the level of the tax unit.

${ }^{12} \mathrm{We}$ also wanted to contrast perceptions in the recognition group to perceptions in a no-recognition letter group. The church was reluctant to send such a letter, for fears that the mailing would be perceived as a wasteful form of spending. In the end, the church agreed to mail 993 no-recognition letters, which pointed recipients to an existing webpage with information on the church tax. The no-recognition letter recipients were then also invited to the survey. We received only 211 responses from this group, and the survey respondents differed from the respondents in the treatment and control groups in terms of taxable income. In particular, fewer church members from the top income quartile sent back the questionnaire. Due to the small sample size and the unbalanced observable characteristics, we refrain from contrasting survey responses in the treatment group to those in the no-recognition letter group.
} 


\section{Empirical Results}

This section reports and discusses the results of the field experiment. We first test how the treatment affected perceived recognition based on the survey data, and then describe our main results on opt-outs using administrative data.

\subsection{Effect of Treatment Letter on Perceived Recognition}

We first exploit the survey data and show that our treatment successfully shifted the church members' perception of being recognized by the church. Table 1 reports the evidence from OLS regressions of the type

$$
y_{i}=c+\beta T_{i}+X_{i} \gamma+u_{i}
$$

where $T_{i}$ is a treatment indicator and $X_{i}$ is a vector of controls including indicators for income quartiles, single vs. joint filing, respondent age above 35, and place of living in (semi-)urban areas. Given that the focus of our paper is on opt-out decisions, the most direct manipulation check is to test if the treatment has reduced the likelihood of church members holding negative views on the church and the church tax. Therefore, in all regressions the dependent variable, $y_{i}$, indicates that the respondent disagrees with a given positive statement on church payments or on her relation to the church. ${ }^{13}$

Column (1) in Table 1 shows that church members in the treatment group are indeed less likely to hold negative views regarding the recognition they receive for their church payments. Fewer subjects indicate disagreement with the statement "My church tax payments are appropriately acknowledged by the church". The treatment effect is -0.170 ( $p$-value $<0.001$ ), which corresponds to a reduction by 35.5 percent relative to the control group mean of 0.479. Next, columns (2) and (3) evaluate the effect of the recognition treatment on members' willingness to pay, and thus on church loyalty. Column (2) evaluates the statement "I am willing to pay the church tax because the church provides important services." The estimate shows that respondents

\footnotetext{
${ }^{13}$ Survey respondents could choose between "fully agree", "rather agree", "undetermined", "rather disagree", and "fully disagree". $y_{i}$ is coded as one for all respondents stating that they "disagree" or "fully disagree" with a statement, and zero otherwise.
} 
from the treatment group are 4.5 percentage points, or 25.7 percent, less likely ( $p$ value 0.046 ) to disagree with this statement than those in the control group (mean of 0.175). These effects are corroborated in column (3), showing that respondents from the treatment group are 8.8 percentage points, or 17.3 percent, less likely ( $p$-value $<0.01)$ to disagree with the statement "I am willing to pay the church tax because I benefit from church services." While column (4) shows that survey respondents from the treatment group are 5.4 percentage points, or 16.6 percent, less likely ( $p$-value 0.058) to disagree with the statement "My relation to the Protestant Church is close", we find no significant difference between groups for the statement "My relation to the Protestant Church has recently improved" (column (5)). All in all, the results show that survey respondents feel more recognized because of the treatment letter, tend to report better relations to the church, and hold more positive views on making payments to the church. Column (6) reports the average standardized effect (Kling et al., 2004) of the treatment for columns (1) to (5), which is highly significant ( $p$ value $<0.001)$.

We contrast this evidence with the impact of the treatment on perceptions of tax payments to the state. As the treatment expresses recognition for past payments to the church (and not for state taxes), we expect perceptions of state taxes to remain unchanged. This is exactly what we find in columns (7) and (8) of Table 1. Among survey respondents, the treatment does neither affect the perception of how appropriately acknowledged state taxes are (column (7)), nor does it shift the stated willingness to pay state taxes (column (8)). Accordingly, the average standardized effect in column (8) is far from being significant ( $p$-value 0.69).

Coding of the dependent variables as indicators of disagreement and estimating the treatment effects by OLS is not sensitive for our results. A more flexible estimation by ordered probit (i.e., defining $y_{i}$ according to the five Likert scale items, from 1: "fully agree" to 5: "fully disagree") produces very similar findings (see Online Appendix Table A3 for details).

Taken together, the results of the manipulation checks imply that the treatment has successfully and purposefully shifted the church members' perceived recognition for their regular payments to the church. Next, we analyze how the private recognition 
treatment has affected decisions to opt out of church membership.

\subsection{Effect of Recognition on Cumulative Opt-Outs}

We estimate the impact of private recognition on church opt-outs following the logic of an event-study design. The event is the randomized treatment. Our focus is on how this event has affected the cumulative probability of opting out over the following 12 months relative to the counterfactual of not receiving the private recognition letter.

In the following, the outcome of interest is a month $t$-specific indicator for opting out, $y_{i t}$, for individual church member $i{ }^{14}$ We define $y_{i t}$ such that is captures optouts in a cumulative manner: It is zero for all church members at $t=0$ (month of treatment), switches to one if an opt-out occurs in a given month after treatment, and continues to take value one for all remaining months up to $t=12$. To identify the causal effect of private recognition on opt-outs, we use the OLS regression

$$
y_{i t}=\sum_{t=1}^{12} \delta_{t} m_{t}+\sum_{t=1}^{12} \beta_{t} T_{i} \times m_{t}+X_{i 0} \gamma+u_{i t}
$$

where $m_{t}$ is an indicator for month $t$ after treatment $T$. Note that we estimate a full set of 12 month effects and an interaction term $T_{i} \times m_{t}$ for all months after treatment (no constant included). Following standard procedures in the literature, the estimates account for strata variables $X_{i 0}$. If no further baseline characteristics $X_{i 0}$ are included, for any given month, $\delta_{t}$ thus indicates the cumulative probability of an opt-out between the month of treatment $(t=0)$ and month $t=1, \ldots, 12$ in the control group, while $\beta_{t}$ shows the month-specific difference in the cumulative opt-out probabilities of the treatment and control groups. To account for the fact that some individuals belong to the same tax unit (couples where both spouses are Protestants), we cluster standard errors at the level of the tax unit.

Note that if the treatment reduces opt-outs, the population at risk of opting out differs between treatment and control group from $t=2$ onwards. Unlike a survival analysis, our approach does not aim at correcting for this type of treatment-induced

\footnotetext{
${ }^{14} \mathrm{We}$ ignore the extremely rare case (92 observations) of opting in conditional on a previous posttreatment opt-out.
} 
selection effect. As we are mostly interested in understanding the cumulative dynamics induced by the treatment, we rather allow this difference to affect opt out rates in later months.

Figure 1 displays our key results for the estimation sample by reporting the monthspecific differences in the cumulative opt-out probabilities between treatment and control group. For ease of interpretation, the graph shows relative effects, constructed by dividing the estimated $\beta_{t}$ 's by the cumulative opt-out probability in the control group in the respective month. ${ }^{15}$

Figure 1 shows that the treatment effects are negative for all months, even though imprecisely estimated for the first months after treatment. This is because the average monthly opt-out rate is only about 0.13 percent. This implies that, in the first months after treatment, even the cumulative effects reported in Panel B rely on a relatively small number of opt-outs. ${ }^{16}$ With an increasing number of opt-outs over time, the estimates become more precise. For months 7 to 10 after treatment, the treatment effects are significantly different from zero at conventional levels ( $p$-values of 0.050 , $0.038,0.022$, and 0.098 , respectively), indicating that the private recognition letter has diminished the cumulative opt-out rate by as much as 9.7 percent.

Starting from month 10 after treatment, we observe a diminishing difference in cumulative opt-outs between the treatment and control groups. This is consistent with the notion that the treatment has helped to significantly delay opt-outs by church members who were at the margin of opting out. Given that we consider a one-time recognition letter in a context where church members make significant payments to the church on an ongoing basis, it may not be surprising that the letter loses effectiveness over time. One possible interpretation of the pattern in Figure 1 is that reducing optouts permanently requires renewed efforts from the charity (Sargeant, 2001, 2008).

A cost-benefit analysis reveals that the increased retention due to the intervention had a small positive effect on church finances: A back-of-the-envelope calculation for

\footnotetext{
${ }^{15}$ As documented in the first part of Online Appendix Table A4, the cumulative opt-out probability in the control group shows an almost perfectly linear trend. One year after treatment, 1.6 percent of church members in the control group have opted out. For the point estimates of the $\beta_{t}$ 's and corresponding standard errors, see Online Appendix Table A5.

${ }^{16} \mathrm{As}$ a back-of-the-envelope calculation, the average monthly number of opt-outs in the control group is about $100,000 \times 0.0013 \approx 130$.
} 
the 12 months after treatment shows that church members in the private recognition treatment paid about 33, 220 euro of church taxes more than they would have paid in the absence of the treatment. This exceeds the total cost of the mailing of 20,250 euro. $^{17}$

Online Appendix Tables A4 and A5 document that we obtain almost identical results when excluding strata controls. As mentioned before, using the estimation sample makes sure that we study a sample of church members who have actually made payments to the church in the year before the experiment. This is important, as church members in the treatment group who did not make any payment may perceive the private recognition letter as inappropriate. Yet, the aforementioned Online Appendix tables also show that we obtain similar (but somewhat weaker) results when using all church members originally sampled.

\subsection{Treatment Effect Heterogeneity in the Cost of Membership}

We next compare responses between different groups of church members. We focus on the cost of membership in the year prior to the experiment as the dimension of heterogeneity, for two reasons. First, the recognition expressed is identical for all church members in the treatment group. Yet, the cost of church membership varies widely between members. Therefore, high- and low-paying church members might perceive the letter differently. Second, although meant to express private recognition, the letter may also have served as a reminder for individuals who previously thought about opting out, but then did not terminate their membership. The literature shows that, generally, reminders can significantly shift behavior (Apesteguia et al., 2013; Altmann and Traxler, 2014). In the charitable giving context, unintended consequences of reminder messages, like unsubscriptions from mailing lists, are not uncommon (Damgaard and Gravert, 2018). ${ }^{18}$ If the letter has reminded (some) individuals of the fact that their membership is costly, it may cause church members at the margin of opting out to

\footnotetext{
${ }^{17}$ The calculation is based on the average payment to the church in the estimation sample and the estimated coefficients of the cumulative monthly treatment effects.

${ }^{18}$ Unintended effects of donation solicitations are also documented in the context of university giving, albeit on an aggregated (university) level and not for individuals (Leslie and Ramey, 1988; Cunningham and Cochi-Ficano, 2002), as well as for mass fundraising (Adena and Huck, 2019b).
} 
terminate their membership. This possible reminder effect may play out differently, depending on the cost of membership. In the data, a reminder effect would show up as temporary increase in opt outs immediately after treatment.

As discussed before, in our sample the average payment in baseline year 2013 was 478 euro per year. Table A2 in the Online Appendix reports balancing tests for church members in the bottom and top quartile of membership cost. While the average church member in the lowest quartile pays 76 euro per year only, the average cost in the top quartile is 1147 euro per year, and the membership cost rises to 10, 000 euro or more for church members in the top percentile. In the following, we exploit this stark heterogeneity to study how the private recognition treatment affects opt-outs for more or less costly memberships.

Figure 2 depicts the treatment effects on cumulative opt-outs for church members in the different cost quartiles. Several observations emerge. First, Panel A documents that in the bottom cost quartile, the private recognition letter has triggered a reduction in opt-outs immediately after treatment by 55.3 percent. The effect slowly tapers off in the following months, but remains significantly different from zero throughout the first 10 months after treatment. Second, in contrast, the treatment has increased opt-outs in the top cost quartile (Panel D). The figure shows a strong positive spike in opt-outs immediately after treatment, which points to optimization frictions delaying opt-outs in the absence of the treatment. The point estimate for the first month after treatment indicates that the letter increased opt-outs by 54.5 percent relative to the control group ( $p$-value 0.06). We caution, however, that the confidence interval of the estimate also includes much smaller values. After one month, the spike in optouts tapers off, with cumulative treatment effects quickly converging to zero. This implies that the short-term spike in opt-outs for high-cost memberships did not lead to permanent differences in opt-outs between the treatment and control groups. The resulting negative revenue effects for the church were thus small. Third, the findings for the middle of the distribution are consistent with those for the bottom and the top, although considerably weaker. The pattern in Panel B (second cost quartile) resembles that in Panel A, with negative (but in this case insignificant) cumulative point estimates. Panel $\mathrm{C}$ on the second to top quartile exhibits a (this time statistically 
insignificant) increase in opt-outs immediately after treatment.

Taken together, Figure 2 delivers two insights. First, there is a negative monotonic relation between the cost of membership and the effectiveness of our treatment: the lower the cost of membership, the stronger is the reduction in cumulative opt-outs caused by the recognition letter. This finding can be couched in the notion that private recognition becomes less powerful for recurring donors if their payment is large, or that, as suggested by related evidence on reciprocity as a motive for giving (Falk, 2007), the relative magnitude of recognition matters. Second, for very high-paying church members, the evidence suggests that the letter reminded members of the high cost of their membership.

Young (2019) shows that $t$-statistic-based randomization tests are preferable to clustered or robust standard errors to avoid over-rejecting the null hypothesis of no effect in heterogeneity analyses. We thus probe the robustness of our results using randomization inference. Online Appendix Tables A6 and A7 show the resulting $p$ values to be very similar to those derived from cluster robust standard errors both for the full sample and for the subsamples by cost of membership.

\section{Conclusion}

This paper contributes to the literature on charitable giving, and specifically to an emerging literature on recurring donations. As half of donors worldwide are enrolled in a recurring giving program, recurring donors are of great importance for charitable organizations. Yet, they have remained out of the focus of research. Our study helps filling the void by providing causal evidence on how private recognition affects donor loyalty.

Church members in Germany make significant payments to their church on an ongoing basis, taking the form of a church tax that is obligatory for church members. However, members can avoid paying the tax by opting out of church at any time. Therefore, church membership in Germany is a setting that is akin to a recurring donor scheme. In a randomized field experiment, we manipulate the recognition that members of the Protestant church receive by sending half of them a letter which 
expresses private recognition for past payments.

Our main result is that the private recognition letter increases the retention rate among church members for a period of up to ten months after treatment. The treatment temporarily reduces the cumulative opt-out rate in the treatment group by almost 10 percent relative to the control group. A heterogeneity analysis delivers more nuanced insights. First, there is a negative monotonic relation between the cost of membership and the effectiveness of the treatment, with low-paying church members responding most strongly. Second, among church members in the top cost quartile, we observe a sharp (but temporary) increase in opt-outs immediately after treatment. This spike in opt-outs is consistent with the notion that the recognition letter has reminded high-paying members of the option to terminate their membership.

While the one-time intervention in our experiment was successful in reducing optouts for several months, it did not affect the long-run dynamics of opting out of church membership. As a result, the intervention had only a small positive effect on church finances. More work is needed to explore how charities can use recognition (and other forms of interaction with recurring donors) to induce permanent improvements in donor loyalty.

\section{References}

AdenA, M. and Huck, S. (2019). Giving once, giving twice: A two-period field experiment on intertemporal crowding in charitable giving. Journal of Public Economics, $172,127-134$.

— and - (2019b). Can mass fundraising harm your core business? A field experiment on how fundraising affects ticket sales, WZB Discussion Paper No. SP II 2019-304.

Altmann, S., Falk, A., Heidhues, P., Jayaraman, R. and Teirlinck, M. (2019). Defaults and donations: Evidence from a field experiment. Review of Economics and Statistics, 101 (5), 808-826.

- and Traxler, C. (2014). Nudges at the dentist. European Economic Review, 72, 19-38.

Andreoni, J. and Payne, A. A. (2013). Handbook of Public Economics, Elsevier, B.V., vol. 5, chap. Charitable Giving, pp. 1-50.

— and SERra-Garcia, M. (2019). Time-inconsistent charitable giving, NBER Working Paper No. 22824. 
— and - (2019b). The pledging puzzle: How can revocable promises increase charitable giving?, CESifo Working Paper No. 7965.

ANik, L., Norton, M. I. and ARIELY, D. (2014). Contingent match incentives increase donations. Journal of Marketing Research, 51, 790-801.

Apesteguia, J., Funk, P. and Iriberri, N. (2013). Promoting rule compliance in daily-life: Evidence from a randomized field experiment in the public libraries of Barcelona. European Economic Review, 64, 266-284.

Ashraf, N., BANDIERA, O. and JACK, B. K. (2014). No margin, no mission? A field experiment on incentives for public service delivery. Journal of Public Economics, 120, 1-17.

Bagot, K. L., Murray, A. L. and Masser, B. M. (2016). How can we improve retention of the first-time donor? A systematic review of the current evidence. Transfusion Medicine Reviews, 30 (2), 81 - 91.

Breman, A. (2011). Give more tomorrow: Two field experiments on altruism and intertemporal choice. Journal of Public Economics, 95, 1349-1357.

ChetTy, R., SAEZ, E. and SANDOR., L. (2014). What policies increase prosocial behavior? An experiment with referees at the Journal of Public Economics. Journal of Economic Perspectives, 28, 169-188.

Chuan, A., Kessler, J. B. and Milkman, K. L. (2018). Field study of charitable giving reveals that reciprocity decays over time. Proceedings of the National Academy of Sciences, 115 (8), 1766-1771.

COUnCIL For AdVANCEMENT AND Support of EducATion (2019). 2018 Voluntary Support of Education, https://www.case.org/resources/2018-voluntary-supporteducation.

Cunningham, B. M. and Cochi-Ficano, C. K. (2002). The determinants of donative revenue flows from alumni of higher education: An empirical inquiry. Journal of Human Resources, 37 (3), 540-569.

DAmgaARD, M. T. and GRAVERT, C. (2018). The hidden costs of nudging: Experimental evidence from reminders in fundraising. Journal of Public Economics, 157, 15-26.

Dwenger, N., Kleven, H., RAsul, I. and Rincke, J. (2016). Extrinsic and intrinsic motivations for tax compliance: Evidence from a field experiment in Germany. American Economic Journal: Economic Policy, 8 (3), 203-232.

FALK, A. (2007). Gift exchange in the field. Econometrica, 75 (5), 1501-1511.

Ferman, B. and Pinto, C. (2019). Inference in differences-in-differences with few treated groups and heteroskedasticity. Review of Economics and Statistics, 101 (3), $452-467$. 
FosgaArd, T. and Soetevent, A. R. (2018). Promises undone: How committed pledges impact donations to charity, Tinbergen Institute Discussion Paper 2018/044-VII.

GilAD, Z. and LEVONTIN, L. (2017). The effect of information about previous donation impact on recurring donations. In A. Gneezy, V. Griskevicius and P. Williams (eds.), NA - Advances in Consumer Research, vol. 45, Association for Consumer Research, Duluth, MN, pp. 1074-1074.

GRANT, A. M. and Gino, F. (2010). A little thanks goes a long way: Explaining why gratitude expressions motivate prosocial behavior. Journal of Personality and Social Psychology, 98 (6), 946-955.

KENNEDY, P. E. and CADE, B. S. (1996). Randomization tests for multiple regression. Communications in Statistics-Simulation and Computation, 25 (4), 923-936.

Kling, J., Liebman, J., KATZ, L. and SANBOnMATSU, L. (2004). Moving to opportunity and tranquility: Neighborhood effects on adult economic self-sufficiency and health from a randomized housing voucher experiment, Princeton University Working Paper No. 5.

Kosfeld, M. and Neckermann, S. (2011). Getting more work for nothing? Symbolic awards and worker performance. American Economic Journal: Microeconomics, 3, 86-99.

Lacetera, N., Macis, M. and Mele, A. (2016). Viral altruism? Charitable giving and social contagion in online networks. Sociological Review, 3, 202-238.

LANDRY, C. E., LANGe, A., List, J. A., PRice, M. K. and Rupp, N. G. (2010). Is a donor in hand better than two in the bush? Evidence from a natural field experiment. American Economic Review, 100, 958-983.

LESLIE, L. L. and RAMEY, G. (1988). Donor behavior and voluntary support for higher education institutions. Journal of Higher Education, 59 (2), 115-132.

LEVIN, T., LEVITT, S. D. and List, J. A. (2016). A glimpse into the world of high capacity givers: Experimental evidence from a university capital campaign, NBER Working Paper No. 22099.

List, J. A., Murphy, J. J., Price, M. K. and JAmes, A. G. (2019). Do appeals to donor benefits raise more money than appeals to recipient benefits? evidence from a natural field experiment with pick.click.give., University of Alaska Anchorage, Department of Economics Working Paper No. 2019-07.

McCullough, M. E., Kilpatrick, S. D., Emmons, R. A. and Larson, D. B. (2001). Is gratitude a moral affect? Psychological Bulletin, 127, 249-266.

NonProfit TeCH For Good (2019). 2018 GLOBAL Trends in Giving Report, https://www.nptechforgood.com/2018/09/15/22611/. 
Notarantonio, E. M. and Quigley, C. J. (2009). An investigation of the giving behavior of loyal, lapsed, and non-givers to a religious organization. International Journal of Nonprofit and Voluntary Sector Marketing, 14 (3), 297-310.

Perez-Truglia, R. and Cruces, G. (2017). Partisan interactions: Evidence from a field experiment in the United States. Journal of Political Economy, 125 (4), 1208-1243.

RAND, D. G., Greene, J. D. and NowAK, M. A. (2012). Spontaneous giving and calculated greed. Nature, 489, 427-430.

Rooney, P., OtToni-Wilhelm, M., WAng, X. and Han, X. (2019). Dynamics of American Giving: Descriptive Evidence, Mimeo, Indiana University Lilly Family School of Philanthropy.

SAMEK, A. and LONGFIELD, C. (2019). Do thank-you calls increase charitable giving? expert forecasts and field experimental evidence, Mimeo, University of Southern California.

SARgEAnT, A. (2001). Relationship fundraising: How to keep donors loyal. Nonprofit Management \& Leadership, 12 (2), 177-192.

- (2008). Donor retention: What do we know and what can we do about it, Report for the Association of Fundraising Professionals, Washington DC.

Scharf, K., Smith, S. and Ottoni-Wilhelm, M. (2017). Lift and shift: The effect of fundraising interventions in charity space and time, CESifo Working Paper No. 6694.

Slemrod, J., Rehman, O. U. and Waseem, M. (forthcoming). How Do Taxpayers Respond to Public Disclosure and Social Recognition Programs? Evidence from Pakistan. Review of Economics and Statistics.

StATistisches Bundesamt (2019). 2019 Statistisches Jahrbuch.

YounG, A. (2019). Channeling fisher: Randomization tests and the statistical insignificance of seemingly significant experimental results. Quarterly Journal of Economics, 134 (2), 557-598. 


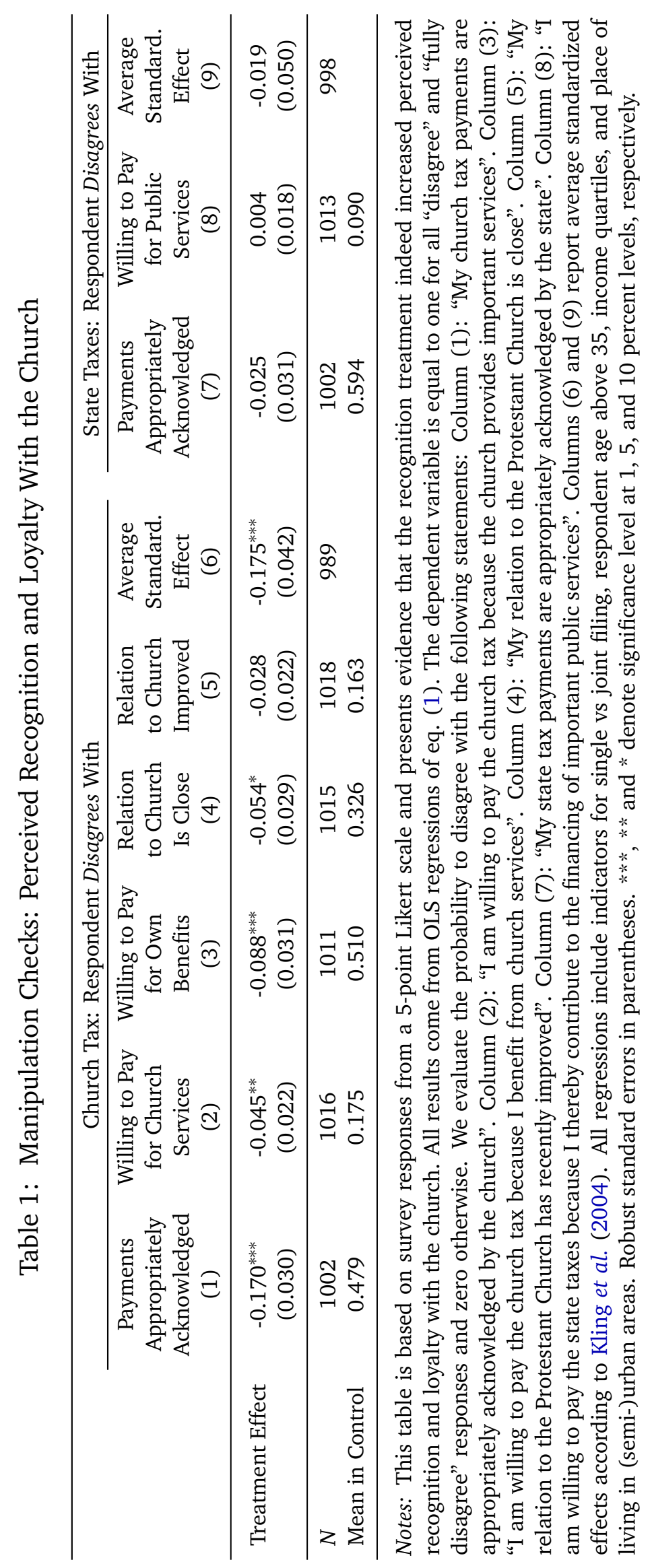


Figure 1: Effect of Private Recognition on Cumulative Opt-Outs

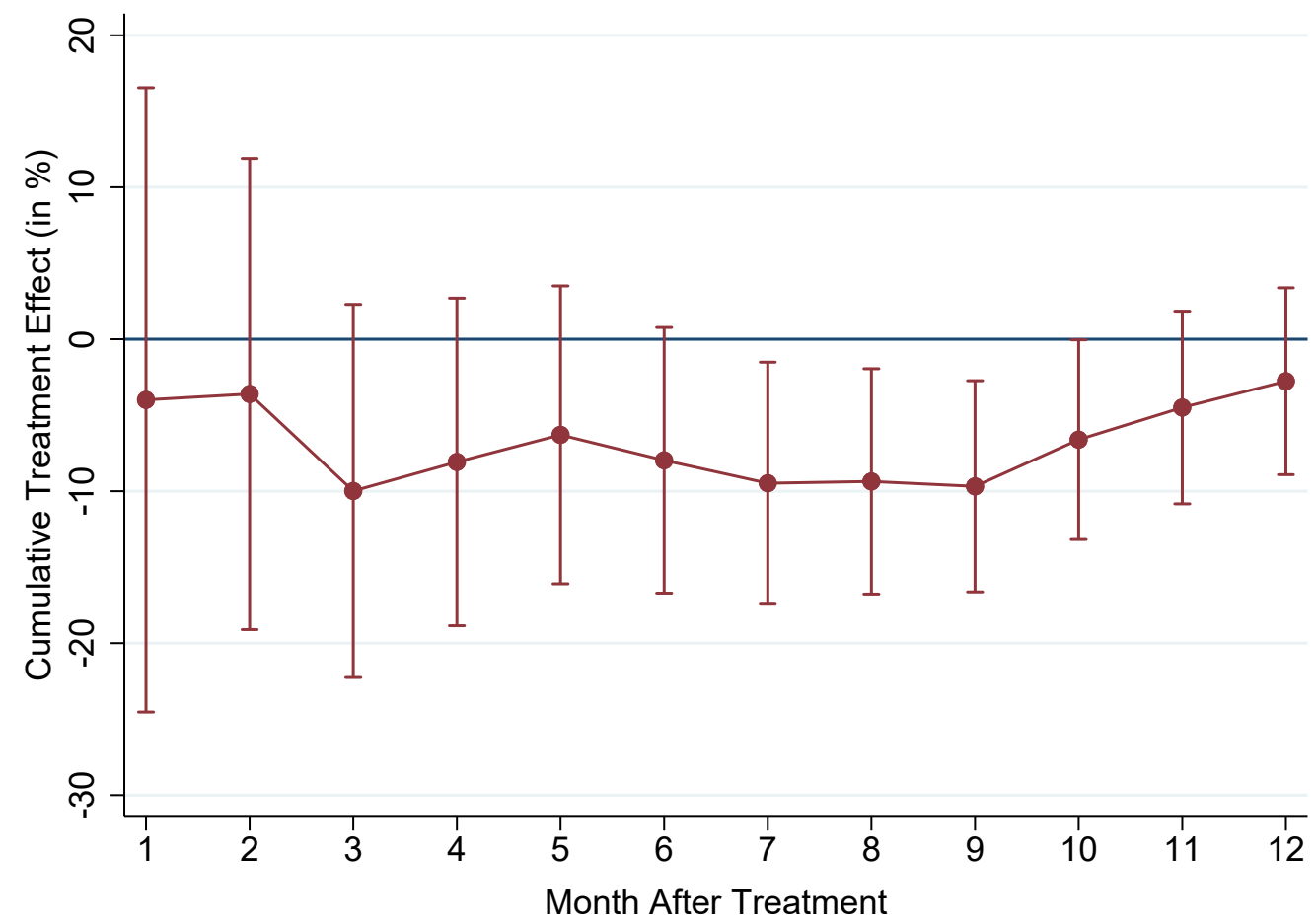

Notes: This figure shows cumulative monthly effects of the private recognition treatment on the opt-out rate relative to the month-specific cumulative opt-out rate in the control group. The whiskers indicate $90 \%$ confidence intervals accounting for clusters at the level of the tax unit (individual or married couple). The sample consists of $N \times T=200,784 \times 12=2,409,408$ observations. The point estimates are reported in Online Appendix Table A5, column (1). 
Figure 2: Heterogeneity with Respect to Cost of Membership
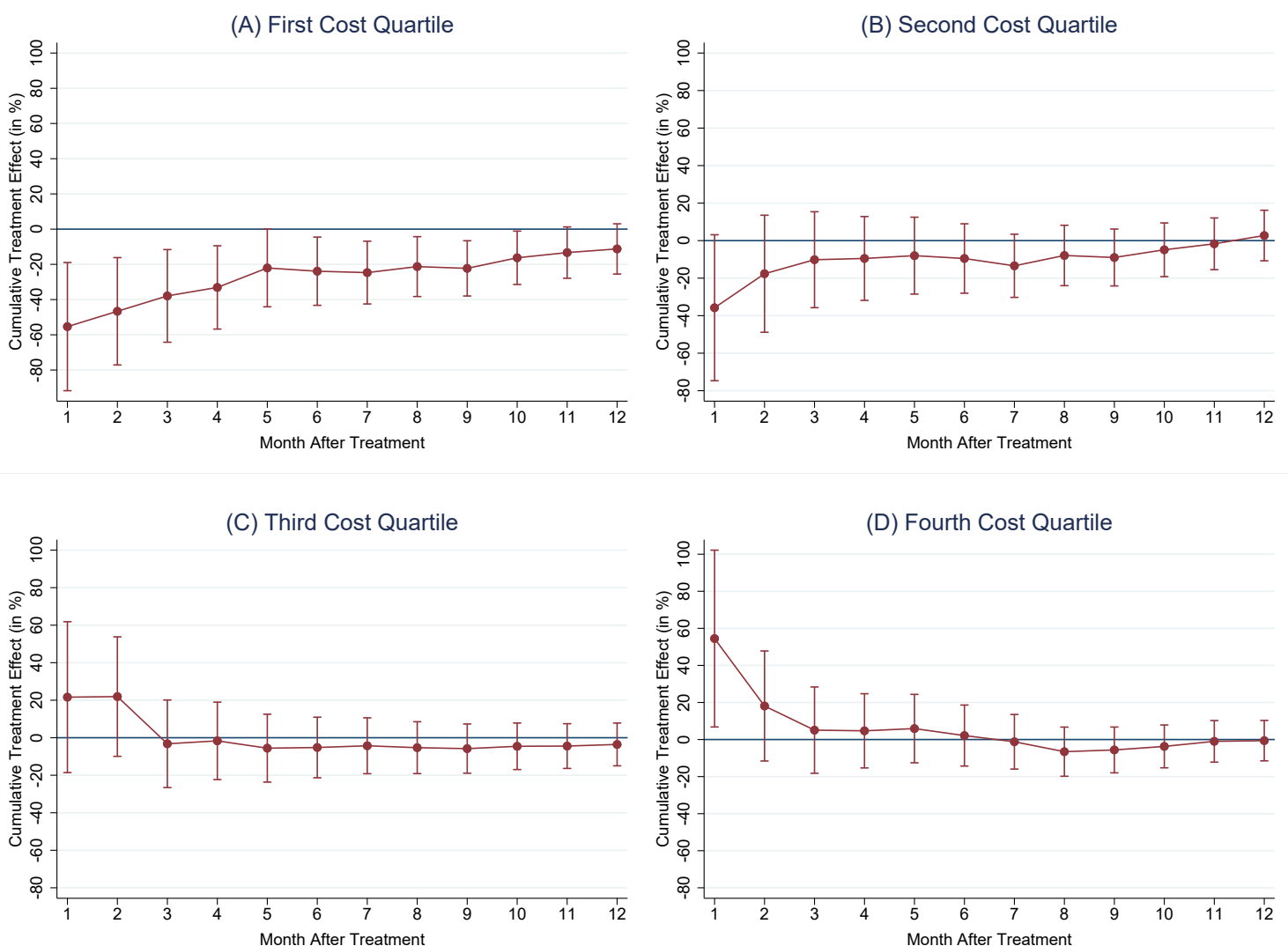

Notes: The figure depicts the heterogeneity of treatment effects by the cost of membership. All panels depict relative cumulative treatment effects by month. Panel A shows the lowest cost quartile. Panel B reports the effects for the second cost quartile, Panel C for the third cost quartile, and Panel D for the top cost quartile. The cost of membership is equal to the annual church tax payment and measured in baseline year 2013. The whiskers indicate $90 \%$ confidence intervals accounting for clusters at the level of the tax unit (individual or married couple). Details on the underlying estimation (including sample sizes) are reported in Online Appendix Table A5, columns (2) to (5). 


\section{Online Appendix (Not For Publication)}

Figure A1: Letter Treatment Expressing Private Recognition

\section{Evangelical Lutheran Church in Bavaria Church Tax Office [name of office]}

Recipient's address

Contact details of the Church Tax Office: phone and telefax number, email address

Date

Tax ID printed here

Your church tax payment

Dear <salutation and name>,

As a member of the Evangelical Lutheran Church in Bavaria you pay the church tax. On behalf of the Evangelical Lutheran Church in Bavaria, with this letter I would like to thank you cordially for your church tax payment in the past year.

The amount of church tax that you pay depends directly on the income tax. With your taxes you make an important contribution to our community.

Yours sincerely,

Chairman

Signature of the chair(wo)man 
Figure A2: Questionnaire for Post-Treatment Survey

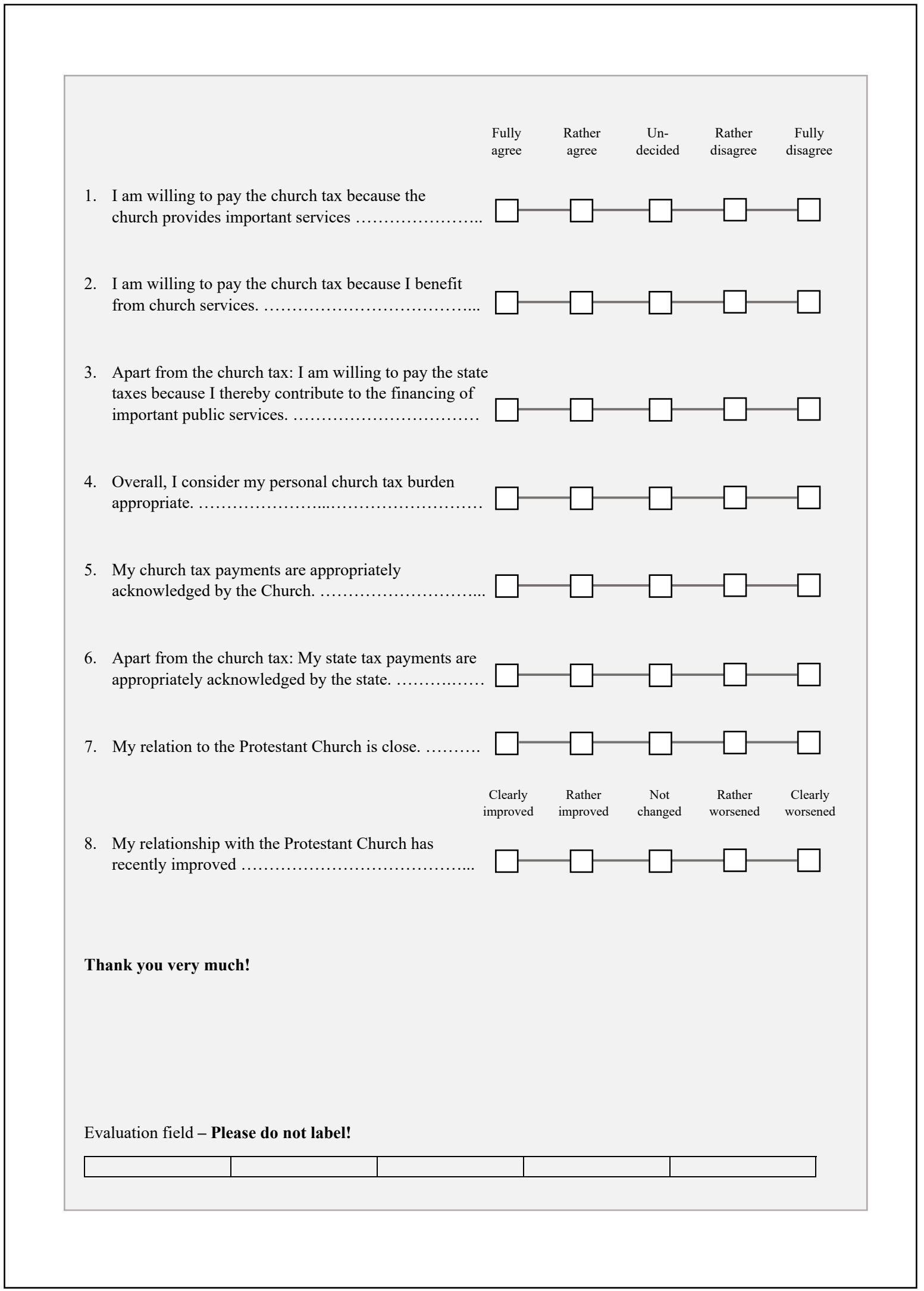


Table A1: Descriptives and Balancing Checks

\begin{tabular}{|c|c|c|c|}
\hline & $\begin{array}{c}\text { Treatment } \\
\text { (1) }\end{array}$ & $\begin{array}{c}\text { Control } \\
\text { (2) }\end{array}$ & $\begin{array}{c}p \text {-value } \\
\text { (3) }\end{array}$ \\
\hline \multicolumn{4}{|l|}{ A: Randomized Field Experiment (Individuals) } \\
\hline Taxable Income in 2013 (euro) & 48,960 & 48,834 & 0.33 \\
\hline Is in First (Bottom) Income Quartile in 2013 & 0.177 & 0.180 & 0.08 \\
\hline Is in Second Income Quartile in 2013 & 0.202 & 0.201 & 0.35 \\
\hline Is in Third Income Quartile in 2013 & 0.313 & 0.315 & 0.19 \\
\hline Is in Fourth (Top) Income Quartile in 2013 & 0.309 & 0.304 & 0.05 \\
\hline Payment for Church Membership in 2013 (euro) & 478 & 477 & 0.72 \\
\hline Age (years) & 45.1 & 45.2 & 0.63 \\
\hline Is Female, no Spouse & 0.175 & 0.177 & 0.42 \\
\hline Is Male, no Spouse & 0.180 & 0.177 & 0.15 \\
\hline Is Female, Spouse Not a Protestant & 0.133 & 0.135 & 0.32 \\
\hline Is Male, Spouse Not a Protestant & 0.148 & 0.146 & 0.19 \\
\hline Is Female, Spouse is a Protestant & 0.182 & 0.183 & 0.63 \\
\hline Is Male, Spouse is a Protestant & 0.182 & 0.183 & 0.63 \\
\hline Lives in Urban Region & 0.285 & 0.284 & 0.81 \\
\hline Lives in Semi-Urban Region & 0.434 & 0.436 & 0.39 \\
\hline Lives in Rural Region & 0.281 & 0.280 & 0.48 \\
\hline Number of Individuals & 100,478 & 100,306 & \\
\hline \multicolumn{4}{|l|}{ B: Survey Respondents (Tax Units) } \\
\hline Is in First (Bottom) Income Quartile in 2013 & 0.159 & 0.156 & 0.87 \\
\hline Is in Second Income Quartile in 2013 & 0.139 & 0.135 & 0.88 \\
\hline Is in Third Income Quartile in 2013 & 0.277 & 0.297 & 0.48 \\
\hline Is in Fourth (Top) Income Quartile in 2013 & 0.425 & 0.412 & 0.68 \\
\hline Age $\geq 35$ & 0.808 & 0.836 & 0.24 \\
\hline Is Female, no Spouse & 0.213 & 0.176 & 0.14 \\
\hline Is Male, no Spouse & 0.178 & 0.198 & 0.42 \\
\hline Is Couple & 0.609 & 0.626 & 0.57 \\
\hline Lives in Urban Region & 0.304 & 0.317 & 0.64 \\
\hline Lives in Semi-Urban Region & 0.450 & 0.402 & 0.12 \\
\hline Lives in Rural Region & 0.247 & 0.281 & 0.22 \\
\hline Number of Tax Units & 527 & 495 & \\
\hline
\end{tabular}

Notes: This table shows descriptives and balancing checks. Columns (1) and (2) report means, and Column (3) shows $p$-values of $t$-tests for differences in means between treatment and control. Panel A displays balancing checks for the field experiment. The sample consists of all individual church members in the experiment for whom we observe church payments in years 2013 and 2014 and who were not invited to take part in the survey. The indicators showing interactions between gender and spouse characteristics reflect information from tax returns. We code an individual as having a spouse if both individuals file a joint tax return. For couples where only one spouse is member of the Protestant Church, we consider this individual's personal income and payment for church membership, respectively. For couples where both spouses are members of the Protestant Church, the tax records contain only the couple's joint income and joint church tax payment. In these cases, we individualize income and payment information by dividing the respective values for the couple by two. Panel B refers to the sample of survey respondents. Here, the unit of observation is the tax unit (individual or couple). Again, the indicators showing interactions between gender and single vs. couple reflect information from tax returns. For jointly filing couples, the indicator Age $\geq 35$ is based on the average age of both spouses. 
Table A2: Descriptives and Balancing Checks for Bottom and Top Cost Quartiles

\begin{tabular}{lccc}
\hline & $\begin{array}{c}\text { Treatment } \\
(1)\end{array}$ & $\begin{array}{c}\text { Control } \\
(2)\end{array}$ & $\begin{array}{c}p \text {-value } \\
(3)\end{array}$ \\
\hline A: Bottom Quartile of Payments & & & \\
& & & \\
\hline Taxable Income in 2013 (euro) & 30,050 & 30,095 & 0.74 \\
Payment for Church Membership in 2013 (euro) & 75.6 & 75.7 & 0.88 \\
Age (years) & 46.6 & 46.7 & 0.23 \\
Is Female, no Spouse & 0.157 & 0.155 & 0.63 \\
Is Male, no Spouse & 0.098 & 0.094 & 0.12 \\
Is Female, Spouse not a Protestant & 0.186 & 0.188 & 0.82 \\
Is Male, Spouse not a Protestant & 0.120 & 0.115 & 0.09 \\
Is Female, Spouse is a Protestant & 0.220 & 0.225 & 0.19 \\
Is Male, Spouse is a Protestant & 0.220 & 0.225 & 0.19 \\
Lives in Urban Region & 0.258 & 0.256 & 0.70 \\
Lives in Semi-Urban Region & 0.415 & 0.418 & 0.46 \\
Lives in Rural Region & 0.327 & 0.325 & 0.68 \\
\hline Number of Individuals & 25,006 & 25,195 & \\
\hline \hline
\end{tabular}

B: Top Quartile of Payments

\begin{tabular}{lccc}
\hline Taxable Income in 2013 (euro) & 78,318 & 78,502 & 0.56 \\
Payment for Church Membership in 2013 (euro) & 1142 & 1152 & 0.12 \\
Age (years) & 45.5 & 45.4 & 0.26 \\
Is Female, no Spouse & 0.159 & 0.156 & 0.40 \\
Is Male, no Spouse & 0.228 & 0.226 & 0.76 \\
Is Female, Spouse not a Protestant & 0.106 & 0.108 & 0.54 \\
Is Male, Spouse not a Protestant & 0.220 & 0.226 & 0.11 \\
Is Female, Spouse is a Protestant & 0.143 & 0.142 & 0.55 \\
Is Male, Spouse is a Protestant & 0.143 & 0.142 & 0.55 \\
Lives in Urban Region & 0.358 & 0.356 & 0.63 \\
Lives in Semi-Urban Region & 0.434 & 0.440 & 0.24 \\
Lives in Rural Region & 0.208 & 0.2004 & 0.37 \\
\hline Number of Individuals & 25,306 & 24,881 & \\
\hline
\end{tabular}

Notes: This table shows descriptives and balancing checks for individual church members in the bottom (Panel A) and top (Panel B) quartile of baseline payments. Columns (1) and (2) report means, and column (3) shows $p$-values of $t$-tests for differences in means between treatment and control. The indicators showing interactions between gender and spouse characteristics reflect information from tax returns. We code an individual as having a spouse if both individuals file a joint tax return. 


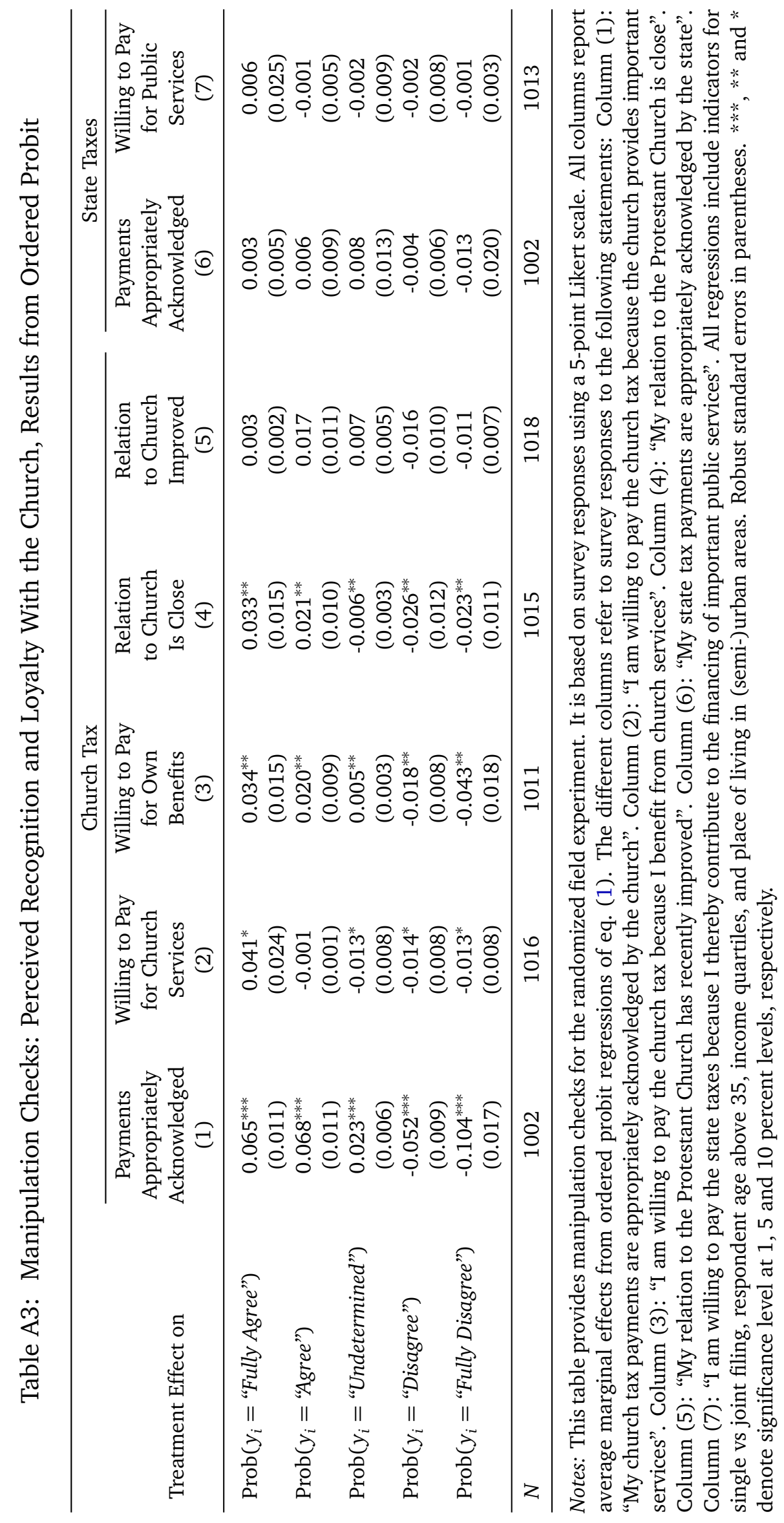




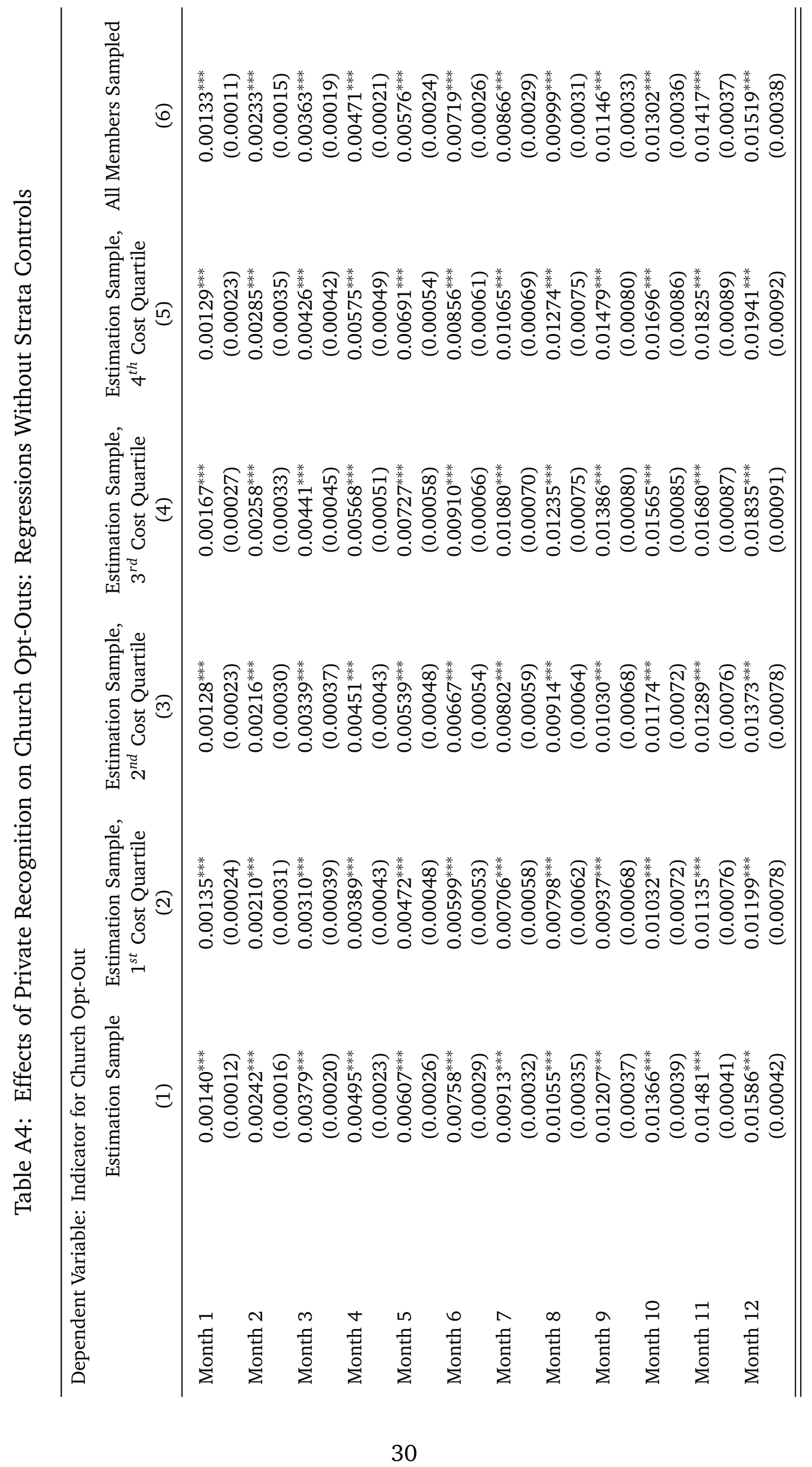




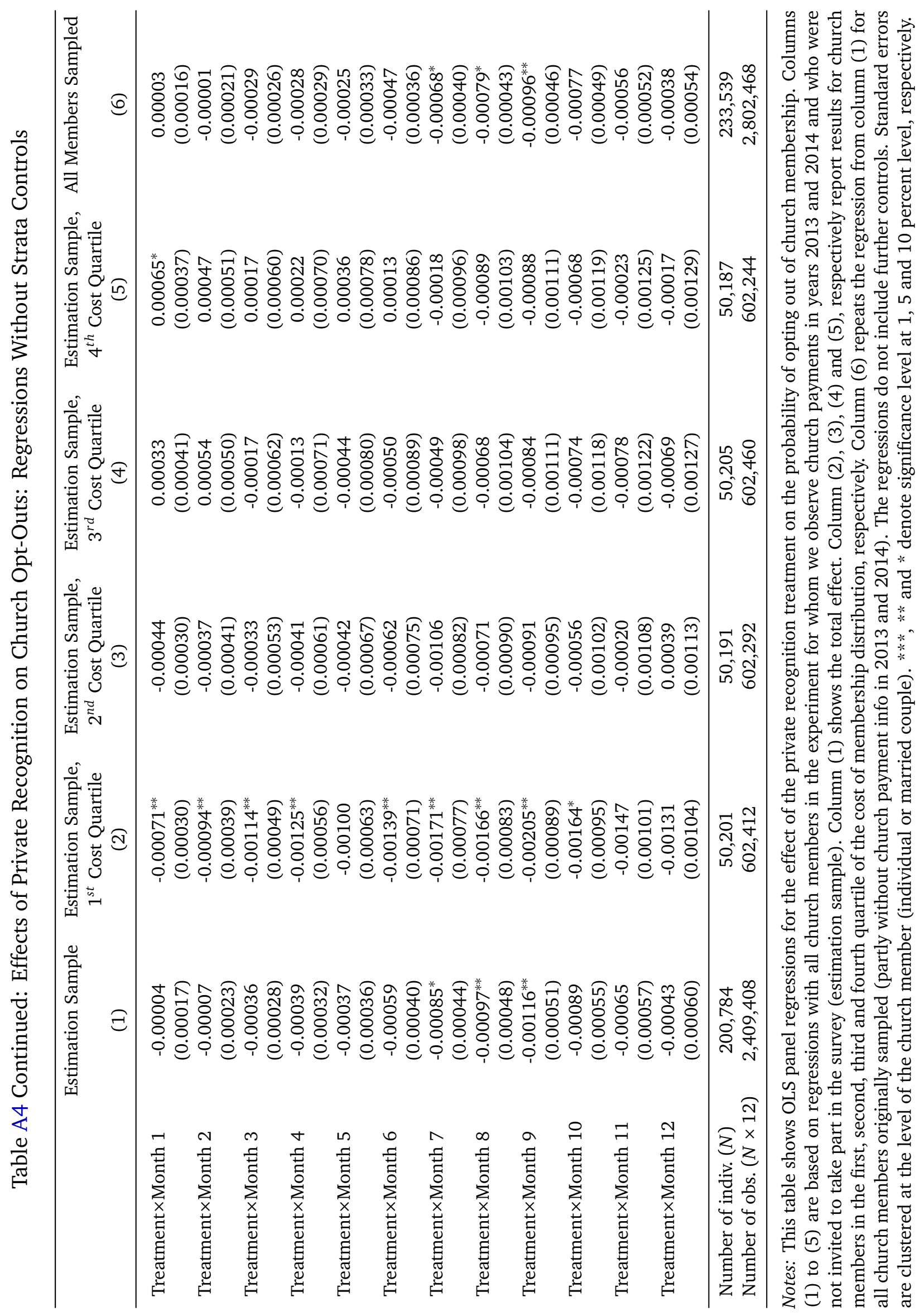




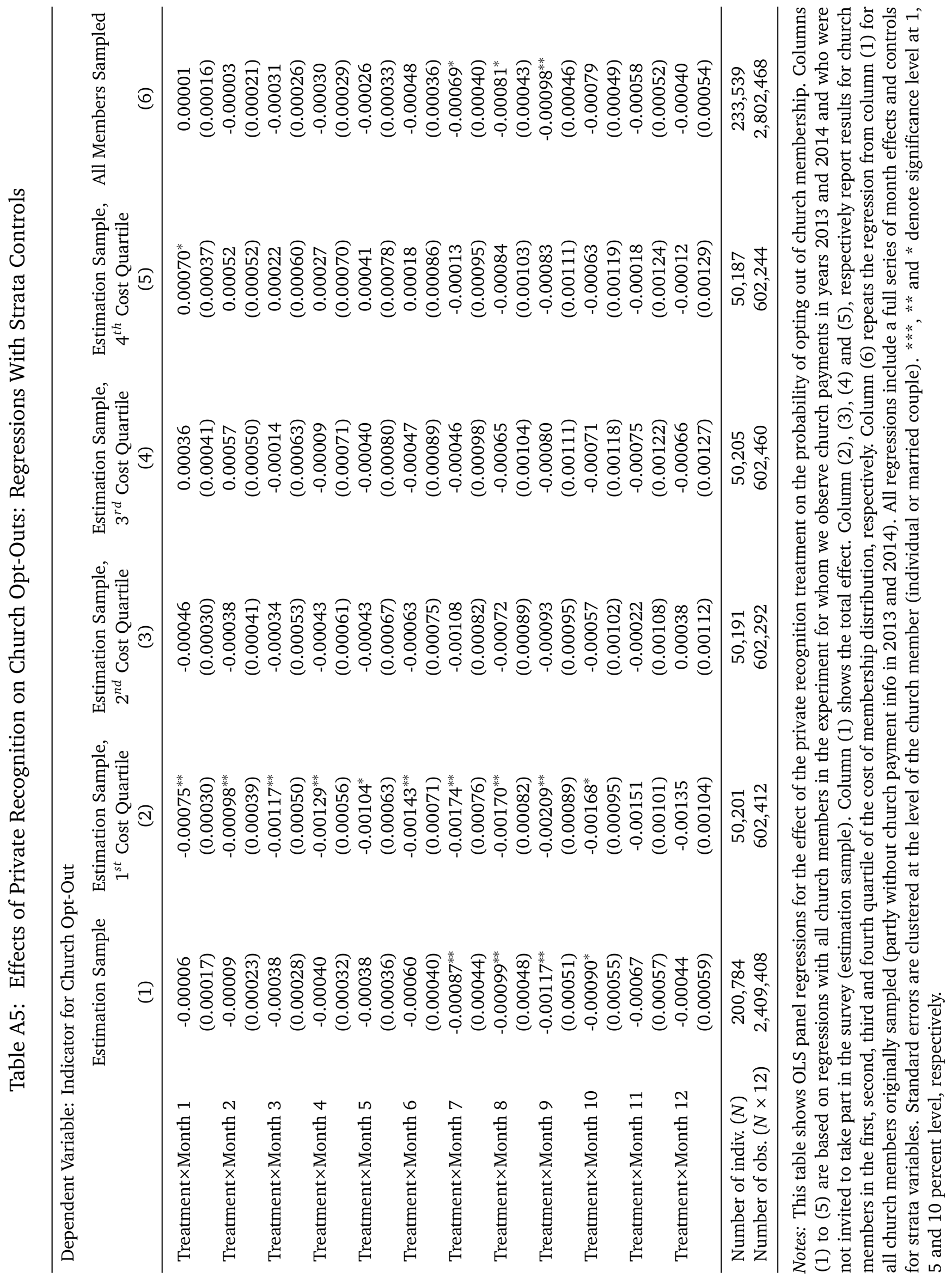




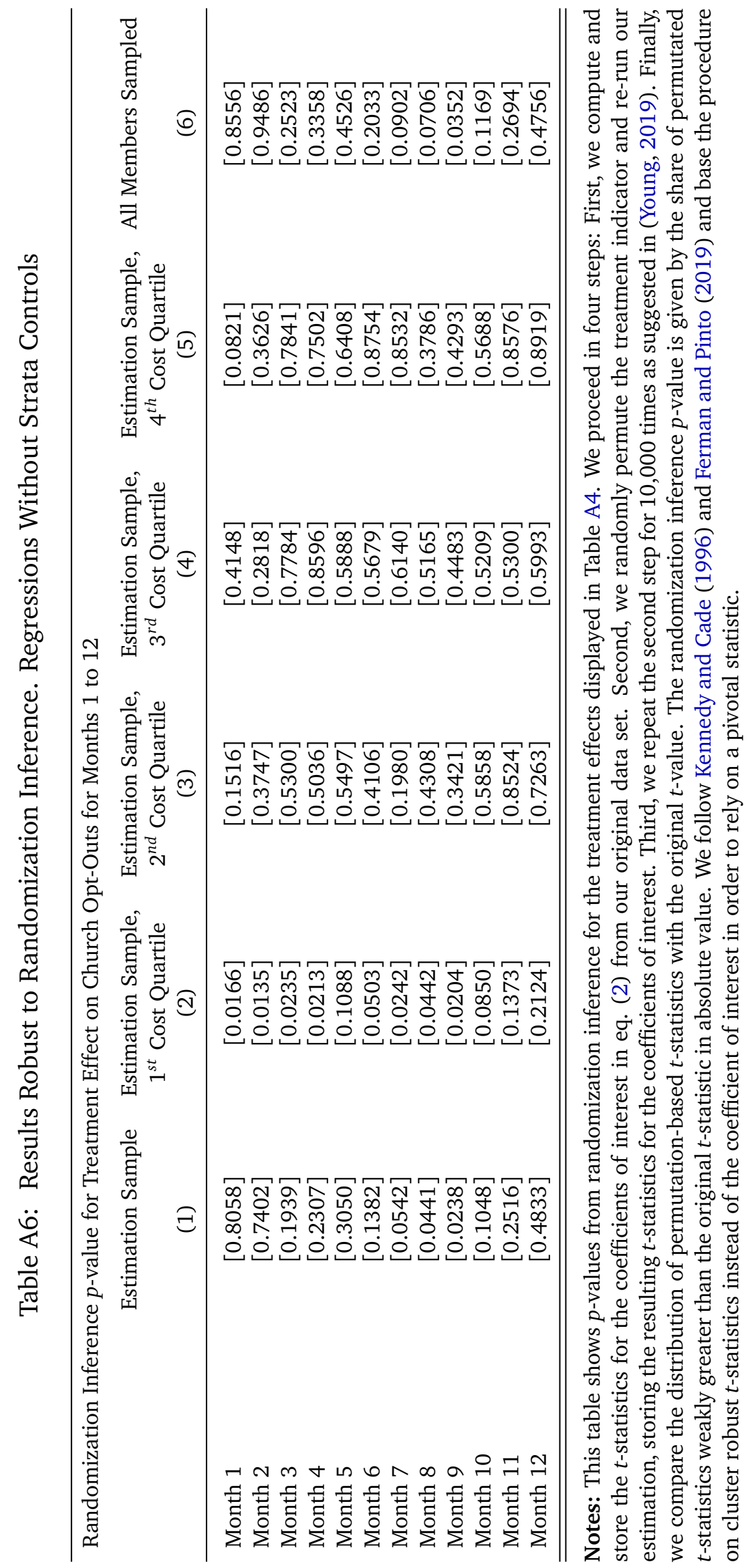




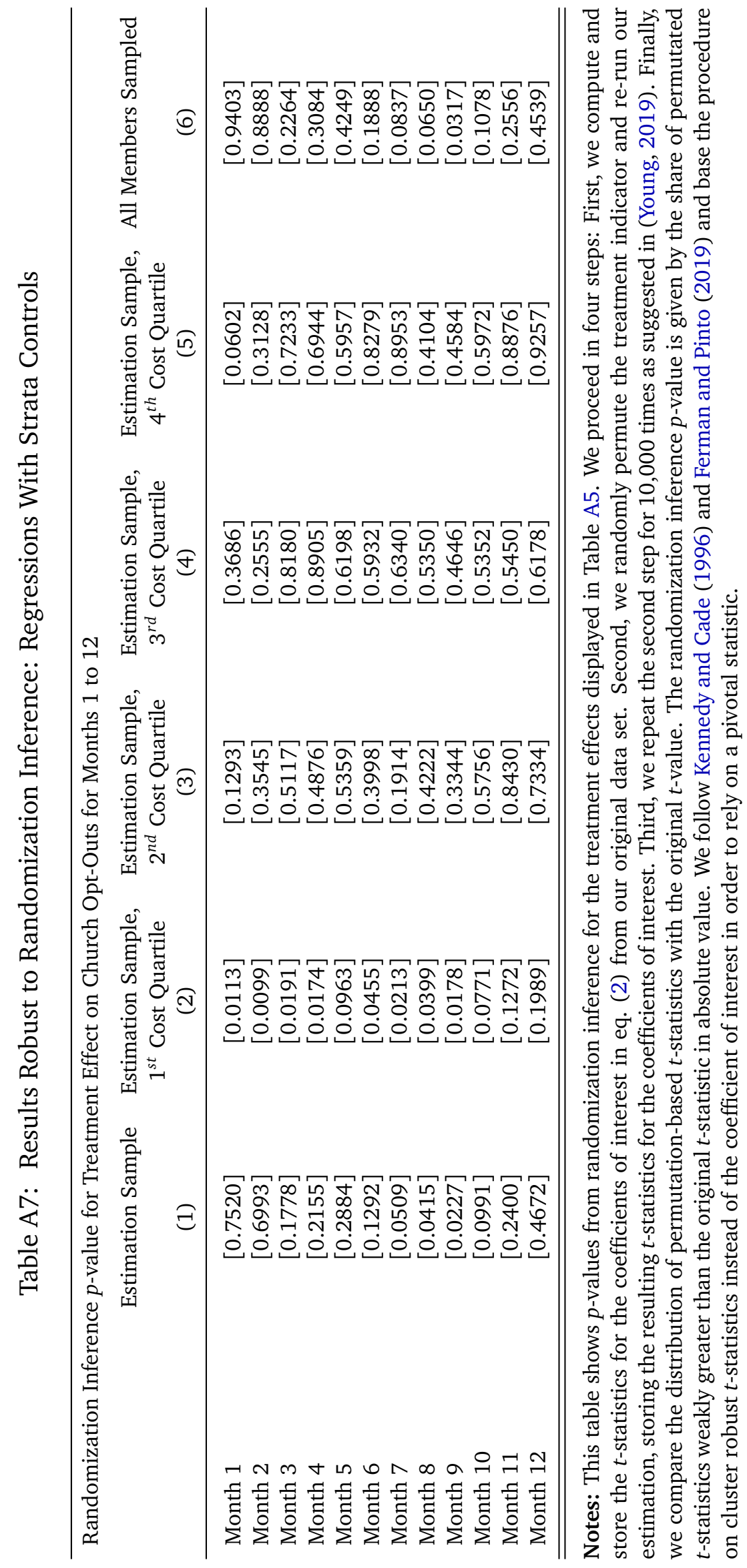

